\title{
Circling the Spheres: A Dialogue
}

\section{Citation}

Buell, Lawrence. 1998. Circling the spheres: A dialogue. American Literature 70(3): 465-490.

\section{Published Version}

http://dx.doi.org/10.2307/2902706

\section{Permanent link}

http://nrs.harvard.edu/urn-3:HUL.InstRepos:2634395

\section{Terms of Use}

This article was downloaded from Harvard University's DASH repository, and is made available under the terms and conditions applicable to Other Posted Material, as set forth at http:// nrs.harvard.edu/urn-3:HUL.InstRepos:dash.current.terms-of-use\#LAA

\section{Share Your Story}

The Harvard community has made this article openly available.

Please share how this access benefits you. Submit a story.

\section{Accessibility}


Prologue Imagine this conversation taking place among Americanists in some English Department lounge at the end of the semester. Taking quite literally Cathy Davidson's call, I have made no attempt to specify the speakers' age, rank, gender, and ethnicity. As their comments should make clear, Speaker A is the most self-consciously politicized of the three, Speaker B the most likely to push in new directions with impetuous verve, and Speaker $C$ the most inclined to try to sum matters up. None is intended as a straw person; though none represents the author's viewpoint consistently, all do at various points.

A: "No More Separate Spheres!" - what sort of agenda does that imply? Is $A L$ suddenly trying to undercut women's studies? To parody the old rallying cry? ${ }^{1}$ Or do we have here an oblique proclamation of feminist revisionism's victory? Or a sweeping claim for its transferability as a model for dealing with issues of cultural division across the board?

B: Nothing so extravagant as any of those, I think. Seems to me that what we're looking at is just a very nineties kind of discontent with simplistic conceptions of difference of all sorts, like that Transition issue "Beyond Identity" a few years back or Judith Butler's reconception of sex and gender in terms of performance. ${ }^{2}$

c: Maybe not so much retheorizing as rehistoricizing. Separate spheres is context specific, after all. Obviously, for antebellum bourgeois culture, the American locus classicus, it's a better window onto gender conventions than for the late twentieth century. So "beyond" doesn't necessarily mean "difference doesn't matter" but that it "manifests differently over time." 
A: Still, "beyond separate spheres" smacks of neoconsensualist orthodoxy to me. Not to mention how it plays to the whole planned obsolescence strategy of academic scholarship. One more turn of the crank. You have to change the mantra in order to keep the "original" work coming. Deconstructionism for the seventies, new historicism for the eighties, cultural studies for the nineties, and now this for the fin de siècle. It does have a slightly millenial ring to it, doesn't it? - or apocalyptic?

B: Neither, to my ear, much less a plot to put specialists out of business. I agree that there's something to the idea that our collective existence depends on a tacit understanding between old and young to keep the revisionary process going. But it's cynical to think "planned obsolescence" and not also "replenishment." Likewise, what you stigmatize as "neoconsensualism" has its good side. Look at how balkanized "American literature" has become-other fields too. How often do you find yourself sincerely desiring to read most of the articles in a typical issue of $A L$ or $A L H$ ? If this special issue provokes new ways of speaking across all those divides-race, class, gender, sexuality, genre, period, nationality, canonicity, whatever-that would be most welcome.

c: Well, now that we've started with the usual routine of hyperfocusing on the politics of rubric designation, let's deal with substance. What do we talk about when we talk about going "beyond separate spheres"?

B: Since I've cast myself in the apologist's role, I'll dutifully raise my hand first. Obviously, for openers, one implication is that gendered discourse slides around-which makes sense. Just to take an example or two from the era when "separate spheres" was coined, the interregional romance plot for epitomizing North-South division and reconciliation gets generated in antebellum times by women writers like Catharine Maria Sedgwick and particularly Sarah Josepha Hale in Northwood, but then appropriated in the postbellum period by men, like DeForest's Miss Ravenel's Conversion and James's The Bostonians, with predictable results. Meanwhile, regionalism, which starts as pretty much a male project with Dwight's Greenfield Hill, Irving's Knickerbocker yarns, and so on in the early national era, gets taken over by women, Stowe being the pivotal figure, of course. In neither case do the spheres stay separate. 
A: But that's just an X pattern. You're not talking "beyond," just trading places.

B: Wait, that's not the whole story. The binaries get blurred at both stages as well. In the antebellum period there's the phenomenon of male sentimentality, which is only now starting to get discussed, as in that "Fireside Chastity" piece $A L$ ran recently. ${ }^{3}$ And we're only starting to grasp the range of genres it pervaded, not just domestic fiction. Shirley Samuels's collection shows this, for instance. "No one group owns domesticity," as Lora Romero points out. ${ }^{5}$ Conversely, the famous gynocentrism of late-century regionalism needs a lot of qualifying, too, especially if you go beyond the short story and include, say, poetry and nature writing. Think about the Robinsons - both Rowland and E. A. ${ }^{6}$ Or Frost and Masters and Winesburg, Ohio, for that matter. Or Burroughs and Muir. Which isn't to deny the networking among postbellum women regionalists. A lot more work remains to be done on this - following up on Donovan, Fetterley, Pryse, and others - and on ramifying the diversity of practice, as Susan Harris did with sentimental fiction. ${ }^{7}$ Not to mention the very basic recovery work still needed for many figures. Annie Fields was at the center of the Northeastern network, but even now not a great deal is known about her. The same goes for writers like Alice Brown and Celia Thaxter and even Mary Austin. It's still not widely known how good they were. My point is that putting them under the sign of gender isn't the only or even sometimes the best way to map them.

C: Yes, look at Brodhead's treatment of local colorism as constructed by genteel tourism, immigration anxiety, and the like. ${ }^{8}$ Pretty severe on Jewett, but a way of reimagining her project that reopens the question of "resistance" vs. "accommodation" in local color fiction and links the movement with a whole range of late Victorian ethnographic practices. Think of Longfellow's multi-volume series Poems of Places, ${ }^{9}$ the vogue of Anglophone travel writing in the nineteenth century, and so forth. It's not stretching too far to link Jewett to Twain and Kipling, even, as nostalgic-satiric memorializers of regional cultures. Both made their own pilgrimages to New England, remember. My chief interest here would be not in region as such but rather in the post-Dickens, post-Stowe push toward "realistic" rendering of colloquial speech - the vernacularization of writing in the U.S. Even if some genres within realism were roughly gender-tilted, like local 
colorism for women and naturalism for men, the linguistic mimesis project knew no sex.

B: The literary ethnography traditions cut across race lines, too, increasingly as you move into the twentieth century. Chesnutt imitates and satirizes the vernacular; then Toomer, Sterling Brown, and Hurston take it more seriously, partly by breaking down the boundary between commentator and demotic voices. And when you trace that through, you can't pry Toomer apart from Sherwood Anderson, or Hughes from Whitman; and it helps to think Jewett when you think Chesnutt, or Frost when you think Brown. Not to mention the BoasHurston connection-Boas the pioneer theorist of cultural relativism, Hurston, his student, the fictive reconstructor of an Afro-Floridian world. Richard Wright and Gertrude Stein make one of the more striking interracial couples of all time. He seems to have been quite sincere in crediting her with capturing African American speech rhythms in "Melanctha," and she in thinking of him as a fellow genius. ${ }^{10}$ The ethnography model also helps conceptualize highbrow realist projects like the fiction of James and Wharton, as Nancy Bentley shows. ${ }^{11}$

A: Before you get carried away with celebrating black-white linkage via representation of "folk" language and culture, remember the dominance structure in play. Dunbar knew he was expected to sound like Uncle Remus; the patrons of the Harlem Renaissancers demanded "authentic" art. One group's free play was the other's restrictive grid.

B: True enough, but a qualified version of the same point applies to the convention that underlies all realist writing: the narrator's standard English versus the folkspeak of regional characters. It's as much a class issue as a race issue. Also, don't underestimate the extent to which the vernacularization movement implied disaffection across the board with official canons of culture and language. A desire to affirm a more diverse, multivocal culture competed with the desire to contain and control authoritatively that is embedded in realist narrative practice. As Kaplan says, late-century realism was "not a seamless package of triumphant bourgeois mythology"; and Borus is right to see the realists both as denizens of an increasingly commodified marketplace culture and as plebeian advocates..$^{12}$ Look at William Carlos Williams. His favorite poets when he was in college were Dunbar, Kipling, and James Whitcomb Riley. ${ }^{13}$ I suspect these preferences were partly a matter of dialect being an avenue to the 
mass market and partly Williams's way of groping toward some sort of contrarian demotic language through the romantic clichés that kept sidetracking him.

C: Maybe a more promising way of countering separate spheres logic is to begin not with a social division you then try to get through or beyond, but with a conception of literary representation as a comprehensive system that arguably structures all U.S. cultural history-like the theory, or family of slightly variant theories, of laissez-faire capitalism. I'm thinking for example of Fisher's "democratic social space" thesis. He's understandably been pounced upon for conflating race and gender as equivalent forms of "regionalism," but if you're really going to get serious about resisting the logic of difference, there's something to be said for totalization, for letting yourself be bold about reenvisaging U.S. culture as conceptually unified. He's especially inventive in reading texts as outcomes of visual technologies and the culture of entrepreneurship. ${ }^{14}$ Call this "neoconsensualism" if you will, but slinging around pejorative labels doesn’t substitute for seeing how far the theory can take you.

B: At least two other approaches to reimagining American texts without recourse to spheres logic have been gaining ground quite fast of late. One, via the ethical turn, sees writing as moral philosophyI'm thinking, for example, of Dimock's juxtapositions of literary and philosophical/legal treatments of justice. Her readings of particular novels do revolve around issues of race and gender difference, to be sure, but the overarching thesis has to do with the constraints of the genres of ethical and legal discourse as against the literary. Literature deals more complexly with the theory of justice than legal or philosophical theory. At the level of this macro-argument, gender and race considerations become secondary or illustrative, at most. ${ }^{15} \mathrm{My}$ second example is the whole menu of semi-connected projects in and around recent so-called history of the book studies - on authorship, reading, print culture, and so forth-certain aspects of it, anyhow. Here you have the option of taking gender and race into account. Certainly you can approach the demography of the publishing establishment or reading practices as gendered or racialized, authorial self-conception and market strategies as gender-valenced or targeted to specific markets, and so forth. But if your project is print technology, distribution systems, or copyright, then gender-and racebecome more peripheral. ${ }^{16}$ 
A: But why do you want to make them peripheral in the first place? Is the state of the academy so improved these days, much less the state of the nation, that you want to commit yourself to the position that difference is obsolete? Even if you reject essentialism in the abstract, can you afford to throw out "strategic" essentialism? ${ }^{17}$ Is the place of women's writing, black writing, much less Latino and Native American writing in the curriculum all that secure? Have we hired enough women and people of color already? I'm skeptical about this furious brainstorming suddenly precipitated by a call for papers that looks to be about blurring differences. It's so easy to get detoured into loose talk and ignore the social realities. To me the implication that we ought to declare a moratorium on separate spheres looks like a rarefied version of the campaign against affirmative action.

B: I think it's reductive and paranoid to imagine $A L$ as hand-in-glove with Newt Gingrich. Isn't Davidson simply asking us to de-rigidify categories the way even the Census Bureau, for God's sake, looks as if it's going to stop making people check one and only one ethnic identity box. Look at the students we teach these days. More and more are interracial, existing "in the gap or interim between cultures." 18 Pretty soon the majority will be multiple hyphens or ethnic hybrids of some sort, if they aren't already. "America's complexion is browning daily," as Bharati Mukherjee says,$^{19}$ and she's hardly the only one. The categories get increasingly blurry. Our theory has to take account of that, and surely it can do so without going so far as Mukherjee, who wants "to reject hyphenization" altogether, or that California politican, Ward Connerly, who wants to junk racial preferences because he's part African American, part Irish, part Indian, and so forth.

c: Let's be careful about what we're claiming here, people. The social issues and the literary-critical issues are not coextensive. You don't want to assign women and minority authors just because they're women and minority-important though it is to have diversity represented. You don't want to have to rest your case for putting Rudolfo Anaya or Sandra Cisneros on your syllabus on the ground of proportional representation alone. And when you do read women and nonwhite authors, gender and race are not necessarily going to be the only presenting issues. Sometimes they won't even be the issues you want to foreground. Surely we don't want to revert to the days when we were trashing Ellison and Baldwin because they weren't 
Richard Wright. Or rather the correct 1960s-era version of Wright. If you focus on his post-Native Son expatriate avatar, The Outsider, you might want to treat him more in relation to Sartre-or Dostoyevsky, if your text is "The Man Who Lived Underground." Likewise with Toni Morrison-Euripides' Medea is as rich a pretext for Beloved as Margaret Garner's narrative or Uncle Tom's Cabin. Conversely, it's no surprise that Mukherjee's ex cathedra proclamations on hyphen erasure don't completely square with her own creative work. If her fabulistic sendup of Rowlandson's Narrative and The Scarlet Letter in The Holder of the World (Puritan housewife achieves fulfilment by going Indian in both senses of the word) isn't self-consciously ethnicized discourse, I don't know what is.

B: Point taken. I spoke in haste. And the fact that what you're saying seems so much more self-evident now, at least within academia, than it would have in 1970 suggests that we're being asked to do much more than just question the salience or applicability of binaries having to do with gender, race, and such-since, after all, the models for doing that are clearly already in play. The whole trajectory of feminist and African American revisionism has led us toward thinking contingency and invention more than inevitability and essence. That's where we are in the nineties.

c: Yes, in antebellum studies Lora Romero's Home Fronts does a particularly keen job of diagnosing gender, race, and class positions in and around domesticity discourse without reifying them or ceasing to recognize their independence. How to interrogate the binaries without denying their force-that's the project behind the project.

B: What's happening in African American studies impresses me even more, given the long persistence in that field of the literature/cultureof-their-own tradition. Even as Gates continues the work of monumentalizing the continua of African American discourse, he's equally aware of the status of ethnic discourse as performance, as in his Little Tree essay. ${ }^{20}$ In the nineties there's been a striking push in African American studies to go beyond stressing the internal teleology - the literature-of-our-own approach - to develop a comparative approach or scene of negotiation across ethnic or national borders. I'm thinking of Gilroy's Black Atlantic, Sollors on interracialism, Douglas on Manhattan in the twenties. ${ }^{21}$ 
C: True enough. And on the other side, the new wave of "whiteness" studies that Toni Morrison got going-Nelson, Lott, and the rest ${ }^{22}-$ also works from some notion of cultural "exchange" or "ripoff" or whatever (never mind the intratribal disputes here) that presupposes race as construct-though I see a tendency to hold up "minority" perspectives, implicitly if not polemically, as less factitious, more a reservoir of authenticity than "white" perspectives. The premise of whiteness studies, that whiteness constructs itself defensively, can have the effect-unintentionally, perhaps - of reinscribing nonwhiteness as a sphere that whiteness can't penetrate. White America as Amasa Delano.

A: That seems niggling to me. What you're pointing to is simply one of those blind spots that always go with critical insight-in this case, the reconception of whiteness as self-constructed over against racial others.

B: The slippage you're talking about isn't just some gravitational law of literary physics, however, with blindness as "the necessary correlative of the rhetorical nature of literary language." ${ }^{23}$ Contemporary social experience is what creates it. Jane Addams has a lovely aphorism about the theory/practice dilemma: "It is quite obvious that the ethics of none of us are clearly defined, and we are continually obliged to act in circles of habit, based upon convictions which we no longer hold." ${ }^{24}$ In everyday life we repeatedly commit the slippages we've moved partway beyond in our formal analyses. The underlying social problem with which writers and critics struggle is the tendency to treat as inevitable what is known to be historically contingent, to treat the invented as the essential. We throw in the towel and tell ourselves in effect, "OK, she's white and she's black." Or, "Let's face it, 'male' and 'female' are still operable categories." Most people won't put gender fluidity to the test. Or sexual preference. Call it "practical essentialism"-or, better, "inertial essentialism." That's the middle American way. And that's the dead level of conventional thinking we need to get beyond.

A: Yet to the extent that separate spheres mentalities have been-and continue to be-historically important in conditioning thought and social arrangements, it won't do to pretend to evaporate them, either historically or theoretically, notwithstanding that this strategy might 
abstractly be more defensible than reification. The biological fact that racial differences are inconsiderable at the level of DNA doesn't make them so historically or culturally.

B: I quite agree that the alternative to separate spheres is not some quixotic or magisterial evaporation program but reflexive recalibration. Another case in point is the kind of challenge that queer theory poses to "heteronormativity." This seems to have both a schismatic and, so to speak, an ecumenical aspect. It's not just about sexuality but ultimately about disrupting the complacency of a culture that "increasingly fetishizes the normal," as Berlant and Warner put it. ${ }^{25}$ In this sense the agenda reaches way beyond resisting repression of alternative sexualities per se, though doing so obviously remains the central energizing intellectual and politico-ethical commitment. The bipolarity is what enables Michael Moon, for instance, to envisage Leaves of Grass as both a pan-civilizational and specifically sexualist project. $^{26}$

A: Yes, I grant you that this is a case where blurring borders impresses me as a truly radical move, rather than a temporizing one. Where gay studies falls short, it's more apt to be a matter of not going far enough-retention oftentimes of maleness as a privileged category, for example, as Robyn Wiegman argues. ${ }^{27}$

C: The bipolarity that strikes me most in queer studies is more a rhetorical one-an often carnivalesque style vs. a didactic urgency and passion. Thinking of the latter sends me back to your point about the ethical turn. Queer theory seems such a profoundly ethical discourse, despite-indeed because of-any carnivalesque elements. In contemporary American literature, is there a work of social prophecy more passionately ethical than Kushner's Angels in America?

B: What's maybe especially striking about the ethics movement in critical studies as a whole, though, is how quickly "ethics" has become a positive conjure word after having been largely spurned for decades as amateurish, nontechnical, and so forth. For a long while it seemed that Wayne Booth was about the only person willing to admit to doing ethical criticism, except for a few people in rhetoric departments. ${ }^{28}$ Then all of a sudden along came Miller, Siebers, Harpham, Newton, and Norris, ${ }^{29}$ with the sidewash from PhilosophyNussbaum on moral imagination, Rorty on nonfoundational pragma- 
tist thinking about social values, Levinas on the priority of ethics to ontology, Taylor on authenticity ethics, and so forth. ${ }^{30}$ To be sure, there's a sense in which we're all Molierian bourgeois gentilhommes who've been doing ethics all along. It goes with the pedagogical franchise. But what we are witnessing today seems to be a new kind of élan. Gregory Jay gets at this when he proposes ethics as a word for talking about self-conscious teacherly negotiation among categories of identity difference. ${ }^{31}$

C: I see the ethical turn as the product of an uneasy synergy between the desire to achieve a social intervention through critical praxis and an anxiety about the foundations of knowledge.

A: Aren't you suspicious of this "ethical turn," though? Just how ethical is it, really? I worry that "ethics" actually means "retreat from politics," an accommodation of the rightward national shift of power/ knowledge so as to look less like we're rocking the boat. It gives us a convenient Bill Bennett-like protective coloration. ${ }^{32}$ When we pull back from direct assault on "ideology," "ethics" rushes in to persuade us that we're still being socially responsible. And that in turn keeps it from acknowledging its own ideological character.

C: There may be something to that, I agree. But to break the radical right's monopoly on the discussion of ethics is a very good thing. There's also a sense of wanting to recover something valuable that in retrospect seemed to have been lost under (post)structuralism and new historicism. Call it a kind of humanism-although that term is obviously problematic. One good index is the currency of Levinasof his notion of the ethical claim as always already prior to the claims of ontology and epistemology, a claim to which Derrida himself pays tribute. ${ }^{33}$ So too the retrieval of the ethical project in late Foucault. ${ }^{34}$

A: None of this, however, addresses the extreme differences in the way the people we've mentioned define "ethics." When "ethics" can be made to cover "antifoundationalism," "narrativity," "professionalism," "empathy," and "close reading" all at the same time, something must be amiss.

B: Not necessarily. Remember that ancient jeremiad of Arthur Lovejoy's that chided scholars for using romanticism as a rubber-band term? "It has ceased to perform the function of a verbal sign," Lovejoy 
intones disdainfully. ${ }^{35}$ Well, that was fine for making the narrow point that it's helpful to be precise; but it was also deeply silly, because the profusion that bothered him was more a symptom of vitality than of decadence. So with ethics. It's healthy to have it taken up from so many angles-writerly, readerly, the text as transaction, the text as social mirror, ethics as moral code, as dispositional affect, and so forth. Why should there be fewer literary-theoretical discourses than there are ethical systems?

C: I'm no more eager than you are to get into the business of policing what counts as ethical criticism. But we need to think more about how the ethics movement, its critical menu, bears on the separate spheres issue. Insofar as we're simply talking about something like "retrieval of moral agency," I don't see anything novel or promising here. Not that I want to trash agency as such, which is surely another point at which standard critical discourse-with its social constructivist assumptions - doesn't match what on a daily basis we expect of ourselves, our colleagues, our students. But it's hardly useful to go back to belaboring the point that Isabel Archer chooses to return to Osmond at the end of Portrait of a Lady.

B: Point taken. To me the promise of the ethical turn is its potential to help gloss the pandemic "ethicity" of U.S. literary traditions, both the creative and the critical. What is more striking about the way we've come to formulate U.S. literary history than the fact that the figure most often claimed as seminal was a moral essayist? Emerson. Or let's say you depose Emerson and enshrine Stowe, or Fuller, or Douglass as your point of departure. U.S. literary history still looks positively saturated with "ethical consciousness." "Political" and "ideological" are both too narrow to characterize the rhetor's role these figures assume. The realists, the naturalists, and the high modernists all filiate down from this aspiration in one way or another, and the counterhegemonics of the various ethnic renaissances or insurgencies resonate with that reformist mentality in their own semi-autonomous ways. What was it DuBois said about being a proper son of New England? ${ }^{36}$ I don't think Americanists have properly appreciated this family resemblance, maybe because just about the only thing we haven't seriously questioned about our critical approaches is their high seriousness, regardless of party. Imagine how the "mainstream" of British literature would look if we saw it as orienting itself around not Shakespeare or 
even Milton but Samuel Johnson or George Bernard Shaw. That to me may be the most striking mark of a "national difference."

A: Aren't you just reviving Puritan legacy-ism, with the Puritan part left out? Bercovitch et al. have already spelled out pretty fully the argument for the percolating influence of New England triumphalism as the basis of American consensus. ${ }^{37}$

B: What I'm talking about goes back to the Federalist Papers-all authored by writers from the middle states and the South, remember? - as much or more than it does to George Bancroft and Cotton Mather and John Winthrop. Or to Letters from an American Farmer, or Bartram's Travels for that matter. Undoubtedly it has a colonial provenance, but it's not region specific. And I don't see ethical rhetoric as by any means always functioning in the interest of consensus.

c: What I see as trickiest about "ethics" as a master category for Americanists is that we may be talking about a form of interventionlike abolitionist discourse or queer theory - that calls for a sweeping reformation of values that's ventured from, although is not limited to, a specific commitment sphere; but we may also be talking about a kind of history-of-ideas or conceptual-formations approach that seeks to distance itself from any particular social or geographical position. Here I think of literary and cultural theory in the pragmatist tradition of Poirier, Gunn, and others. ${ }^{38}$ I wouldn't go so far as to characterize the critical pragmatist argument the way Paul Jay does, as a veiled nostalgia for essentialism, because it seems to me that, as Cornel West's work shows particularly well, at least in principle it can also become a lens through which to scrutinize the ethno-cultural divisions it doesn't want to be bound by. But Jay gets at the point I'm trying to make when he insists on the importance of taking the "politics of location" into account even if he overstates the contrast between that which does and that which doesn't. ${ }^{39}$ For that's the kind of distinction that's key to what I find most interesting about ethics criticism in the present context, both as rhetorical style in American literary history and as a preoccupation in contemporary critical thought-namely, its ambidextrous capacity to ally itself with either sphere-eliding master narratives or sphere-responsive arbitration of cultural division.

A: Ever since you mentioned the "Emersonian difference," I've been mulling about what I think is arguably the biggest "separate spheres" 
issue of all, even if it's never been explicitly called such. I'm thinking of the whole exceptionalist tradition of thinking about U.S. literature, culture, and mission, which Puritan legacy studies engages and to a large extent illustrates, as does pragmatist theory. Surely we can't leave this room without somehow taking up the question of exceptionalism.

B: Indeed not. I see two key trend lines from the eighties. One is Puritan legacy-ism theory yielding place not only to the pragmatists but also to the neo-imperial thesis that's emerged from some of the revisionary work on westward expansion over the past couple of decades-Slotkin's frontier trilogy, Horsman and Stephanson on manifest destiny, the Smithsonian's West as America exhibit, and so forth. ${ }^{40}$ You see the early results of this in, for example, the Kaplan-Pease anthology on imperialist culture in U.S. history or Cheyfitz's Tarzanism thesis. ${ }^{41}$ If there's anything current right now by way of an emerging unified field theory of American literary/cultural history, I think this has got to be it. Certainly the American Studies Association thinks so, judging from its 1998 convention program. My second point is that the trajectory of this work seems to be not only to assail exceptionalism's claims to respectability as a civil religion - which is hardly a new critique-but also to push U.S. literary studies more toward globalization. At least incipiently. So far this work has been more or less bound to nationally introspective and presentist tropes of Cold Warism, Reaganism, post-Soviet pax Americana, and so forth. As if the end point of the inner teleology of U.S. literary cultural tradition were the version of late-twentieth-century history DeLillo imagines in Underground. But I suspect the long-range consequence will be to reconceive U.S. cultural formations as part of a gradually, irregularly, and transhemispherically constructed combination of anticolonial recoil against and participation in the propagation of Eurocentric institutions globally, a process that began, as Anderson claims, ${ }^{42}$ in the eighteenth century and still continues today, with every significant figure in U.S. literary history from colonial times on down involved in some way, frequently in shifting or paradoxical roles. I foresee-at least I'd like to see-a continuing shift away from constructing U.S. literary history in terms of its internal narratives, let alone a unitary "master narrative."

C: What you're calling for is a very tall order, well-nigh impossible 
to pull off, however worthy in principle. All the standard divisions of labor in academe militate against it. It's a lot easier to call for a globalized reconception of U.S. literary and cultural history than to master the bibliography that allows you to make good on the claim. So the grand vision might either remain imprisoned in a predictable barebones allegory of multinational capitalist nefariousness with the U.S. as arch-villain or else fission into a vast bazaar of manageably specialized crafts-Anglophone Philippine writing, for instance: a rich, unique, century-long body of work but one that requires readers with much broader and multiple horizons. I'm thinking that a modestbut certainly not at all trivial-first step that would test Americanists' powers of stretchability would be for U.S. literary studies to make the "Atlantic culture" move more than it does. Even if it were just a matter of doing a little more by way of Anglo-American comparative work - to reflect more on the status of the jeremiad, say, and regional realism as transatlantic genres. ${ }^{43}$ It's bemusing that only just this year has there appeared a journal devoted to "Anglo-American Literary Relations." ${ }^{44}$

B: I'd certainly agree that the notion of "American" distinctiveness as a basis for organizing thought about U.S. writers-or formulating how they themselves thought about their work - has been overplayed. We don't think enough about the dubiousness of classifying certain writers by nationality: Eliot, James, Stein, Melville. We forget that Melville wrote his first novel for a British audience and ended his career utterly uninterested in American literature as such. How many fiction writers who have toyed with the idea of "the great American novel" have taken it seriously? Besides Dos Passos, maybe.

A: Don't get carried away. True, nationalism as a social program is in disrepute, and as a self-conscious writerly motivation it's fitful. True, the economy has become globalized, and so have popular culture forms. Up to a point, I'm sympathetic to Walter Michaels's exposé of the whole idea of national "identity," American identity anyhow, as specious ethnocentrism..$^{45}$ But obviously the nation-state is far from dead; self-consciousness about national cultural difference is basic to the primal self-legitimation of American literature as a subfield; so even though it may have been overstressed, that same selfconsciousness about national mission, about finding the "distinctive voice" of American literature as a project, has become so historically 
embedded that it's become a historical force of its own, despite whatever evidence points the other way. In other words, we can't abandon it, though of course we shouldn't fetishize it.

B: Agreed. With that caveat, let's proceed. Alongside transatlantics, I want to place hemispherics. One of the major challenges to the traditional self-limitation of the American sphere has been the refashioning of American studies as a hemispheric project. This looks increasingly persuasive given the demographic trend line. Latinos are about to become the largest U.S. minority group and before long will constitute a quarter of the national population. Already several models are in play for reconceiving the construction of hemispheric culture-Sommer's genre approach; the border studies approach of Saldivar and others in Chicano literature, focusing on cultural negotiation, resistance, and hybridization in contact zones; and cultural historiography on the Eurocentric invention of America from O'Gorman to Rabasa, just to name three. ${ }^{46}$ The net effect of these is to underscore the status of Anglo-American culture as $a$ sphere, but only one, and to establish the status of various cultural spheres as historically both potent and fluid.

A: The promise of these models, which I agree are promising, doesn't hinge only on Latino-Anglo relations. I'm chagrined that both now and earlier when we brought up black-white issues our first move has been to frame as a binary what's actually multilateral. There's an interlocking set of variables having to do with Native American cultural history imbricated in different ways with both Chicano and Anglo culture but not coextensive with either, each tradition with its own margin-center dynamics and issues of borders and hybridization, as Vizenor, Krupat, Owens, and others point out. ${ }^{47}$

C: It gets even more complicated than that, actually. The process isn't limited to the Western hemisphere or even the Atlantic world. As I said before-and I meant it-I'm cautious about trying to press very far in a globalizing direction, but this point needs to be made in principle. In terms of ancestral location and culture, the U.S. has the most mixed population of any country in the world. This is an intentional policy-however disputed and threatened at every stage-and U.S. literary history shows this. Much more has been published or recorded in this country in languages other than English than most people realize, and not just in Spanish or Native American languages. 
Consider some of what's being issued in English in the U.S. today by writers we all consider major. Think of the mind-blowing intertextual reach of Kingston's Tripmaster Monkey, which alludes to "a virtual encyclopedia of Asian American history and lore," ${ }^{88}$ and also reaches way beyond that one cultural sphere to reprocess Whitman and Bret Harte from the Yankee repertoire ${ }^{49}$ and a good deal of the European canon to boot, together with classic Chinese literature and mythography. ${ }^{50}$ Somehow we need to construct narratives for U.S. literary history that will do justice to works like this, narratives that are both "local" and "cosmopolitan."

A: How would you go about implementing that, short of commissioning Kingston to write her version of literary history, which of course would be only her version?

C: I don't claim to have it figured out. I'm not learned enough or brave enough to make such a grand attempt. "I am too young yet by some ages to compile a code," to take refuge behind Emerson's charming disclaimer. ${ }^{51}$ But let me not be so poltroonish as to dodge your bullet entirely. For one thing, I'd certainly foreground canonical texts and discourses that have manifested linguistic and/or cultural collision in a significant way, including some of the usual suspects - "Song of Myself" and Moby-Dick and Uncle Tom's Cabin, for instance. I'd want to do much more than is usually done with less studied, hard-to-classify figures who move across cultural divides, like Lafcadio Hearn, who practically tried to remake himself as Japanese even as he laid down the law to Japanese university students about English and American literature; or Charlotte Forten, very self-consciously the abolitionist of color but relishing European literature and art and thinking of it as her proper heritage also. Immigration literature would of course be key, going all the way back to the first settlers and taking into account displacement and blockage, not just assimilation, as per the new diaspora theorists like Lisa Lowe. ${ }^{52}$

B: Don't forget diaspora within U.S. borders: internal migration. Take the case of Bret Harte, whom you mentioned as one of Kingston's signifiers. For reasons I won't bore you with, I've been reading a forgotten novel of his, Gabriel Conroy. That's got to be where Joyce got the name of his protagonist in "The Dead"-which is also about cultural marginalization, migration, and collision, within Ireland. Harte's 
Gabriel is an extremely dense and sexually clueless gentle giant, a kind of defanged mountain man, a proleptic caricature of Joyce's Gabriel. Anyhow, all the characters in this novel, which is basically about making it and not making it in California during Gold Rush days, are displaced persons of one sort or another-Yankees, foreigners, all races-swirling around in a state of social fluidity. In the end, of course, white brains and sentimentality win out. California is clearly on the way to becoming Yankeefied, at a dumbed-down level that looks almost like a textbook example of Berlant's infantile citizenship thesis. ${ }^{53}$ But not unproblematically so. There's a lovely moment where Gabriel is trying to cajole a piece of vital information from a Chinese house-servant. The servant would like to oblige him but feels dutybound not to tell. Gabriel imagines himself superior to the "heathen Chinee," although Gabriel's own Christianity is almost nonexistent and linguistically he's no closer to being able to speak standard English in complete sentences; and it's obvious that the servant's sense of honor and, well, refinement are infinitely greater. Now this servant, in the context of the novel's interminably tangled plot, is just a throwaway character, a bit part. And yet for some reason the book feels the need to create that resonant encounter, a kind of epiphany really, out of the momentary collision of these figures from the Yankee and Chinese diasporas.

A: Of course the seduction of such an "epiphany," as you call it, as a move to avoid disrupting the status quo by deflecting attention onto scenes of private encounter that you wishfully represent as synechdoches of social possibility, is part of Berlant's larger argument. But what I really want to question is the broader issue you raise when you start to go all over the place in search of your intuitions. What besides the fortuitous concatenation of Kingston's whimsy and "books I just happen to be reading at this moment" justifies making such a big deal of Harte?

B: Maybe I got slightly carried away. Still, the truth is that in this postcanonical and paradigm-busted age it gets much harder to specify what the right touchstones are, what I as a "literature specialist" ought to read next. It used to be more clear-cut: major authors in your subfield, critical commentary, a bit of biography and history. Today you can make just as good an argument for reading anthropology, political theory, or history of science. Or soap operas as more key to 
certain projects of high sophistication than the novels of Wharton or James. I'm not saying this is good or bad, just that it happens to be the case.

A: Exactly. And in challenging you on Harte, I didn't mean to exile him. In fact, following Limerick, Gutierrez, et al., ${ }^{54}$ you could make a strong case for taking the still-neglected archive of Western literary history (using "Western" in a moderately elastic way) as your base of operations for retheorizing U.S. literary culture as a whole, including the popular culture forms, indeed especially them-the captivity, the dime novel, the western, western film. I'm saying that the West is arguably even more American than has been claimed. Certainly it's the most durable image of the U.S. on the cultural export market. And if you want to press the case for the U.S. as a diasporic culture of contestation not yet congealed, the West-or rather Wests, from the first frontier of Cooper's Pioneers to the postmodern frontier of L.A. - is the place to go. For still another, western studies fits the postcanonical cultural studies dispensation beautifully - no classics to speak of, no stratification of "high" and "low" cultural forms.

C: I'm getting an acute attack of free-floating-signifier anxiety. What is this "West" we're talking about? A ballet of commodity forms taking shape around different scenes of cultural performance. But where exactly is the place that this is happening? Does L.A. equal the plains of Wyoming equal the Idaho panhandle equal the rainforests of the Cascades? We've got to do a little better than recirculating Baudrillard's platitudes-deserts, freeways, Hollywood ${ }^{55}$

B: In the cultural studies frame of reference, there doesn't need to be a place for place, in the sense of literal geography, except as part of the script. That's really the larger frame of reference here that "the West" as we're discussing it instantiates.

A: Right again. Western history teaches the opposite lesson from what Frederick Jackson Turner thought-not democracy but power struggle and reinscription of hierarchy. But Western cultural forms are a perfect case of cultural studies' leveling of genre hierarchies into social text, within which mountains, deserts, and prairie as land forms become irrelevant; it's their status as cultural icons that counts.

B: I know the argument, but I want to know what you think. Are you 
truly ready to elide place specificity, its material groundedness, from your problematic altogether?

c: Sounds as if we've circled back to where we started, with regionalism. But maybe that's useful?

B: It points us to still another development we haven't talked about: the environmental turn. Which in fact began as a self-conscious movement under the aegis of the Western Literature Association. ${ }^{56}$ That conveniently stretchable umbrella term, "ecocriticism," points to several different kinds of inquiry of direct relevance to a lot of what we've been considering in this conversation on spheres. One is the place/atopia problematic to which we've just alluded, upon which Elder, Ryden, and others reflect-literary and cultural formation as a process of habitation, or "reinhabitation," or "storied residence." The central question here has to do with the place of place in environmental aesthetics. Just how crucial is the phenomenon of rootedness, and in what ways? Another major line of inquiry is the ecofeminist work of, say, Westling and Norwood, building upon but complicating Kolodny's distinctions between men's and women's engagement with natural environments. Still another is the question of localist resistance rhetoric against the march of technotriumphalism-its strategies, its ethics, its feasibility. ${ }^{57}$

C: It's certainly true that if we're looking for a form of critical inquiry that contains within it the potential to achieve a mutual alignment of local, national, and global domains, environmental discourse is a prime candidate. To my mind, so-called ecocriticism has thus far been too focused on outback as against city and on saving nature from civilization to meet that challenge. But a latter-day equivalent of Rachel Carson in the field of cultural studies conceivably might.

A: Maybe so, but enough's enough. Even granting that there might be a place for the environment in U.S. literary studies, right now it's got to give place to time. Let our inventor and those of like mind press the case themselves. If they can. For now, I'm beyond the point of being able to deal with any more beyonds.

B: But surely we ought to reach closure on something? So far all we've produced is running commentary on a ceaselessly proliferating menu.

C: Which makes perfect sense. Smörgasbord is the order of the day- 
multiple semi-interconnected epicenters across an expanding postcanonical tableau, intensified by market demand for instant production cum originality.

B: All margin, no center. Or else the margin has become the center.

A: Not quite. Judging from $A L S$ and the annual $P M L A$ bibliographies, Melville, Twain, Faulkner, and the other great dead white males remain the nodal points to a greater extent than we like to think.

c: True enough, but the conjuring terms these days aren't "canon" and "great books" but "negotiation," "border," "hybridization," and so forth. What's being canonized, if that's the right word for it, isn't any particular assemblage of authors or books but a repertoire of cultural discourses whose collision, fusion, interaction, or whatever constitutes the force field that gives authors, books, and epistemes their templates for identity, such as it is.

B: "Such as it is"-precisely so. An identity in perpetual quotation marks, shifting about with history, with authorial impetus, with critical vantage point.

A: With the hour, you mean. All this sounds mighty nebulous to me. Those who keep shifting their identity, lose their identity. Or never had it.

B: Foundationalist nostalgia isn't the problem for me that it is for you. But I agree that it's part of the story, part of the critical mix.

C: Yes. On the one hand, there's obviously no such thing on the current critical scene as the "Americanist community," maybe never really was, even though we sometimes wish for it and thereby make that wishfulness a part of our artifacts. On the other hand, to the extent that the icon of "negotiation" becomes more or less consensual, as it now is, that reestablishes something like a common coinage, or at least the hope of such.

A: For how long, though? Will it outlast the present conversation?

B: But what else is there?

Harvard University 


\section{Notes}

For their responses to previous versions of this dialogue, my sincere thanks to Adam Bradley, Sacvan Bercovitch, Mary Anne Boelcskevy, Wai Chee Dimock, Jonathan Fortescue, William Handley, Doris Sommer, Werner Sollors, and the participants in the The Americas seminar of Harvard's Center for Literary and Cultural Studies - none of whom should be held responsible for its critical misdemeanors!

1 See Rosalind Rosenberg, Beyond Separate Spheres: Intellectual Roots of Modern Feminism (New Haven: Yale Univ. Press, 1982).

2 Transition 55 (1992); and Judith Butler, Gender Trouble: Feminism and the Subversion of Identity (New York: Routledge, 1990), and Bodies That Matter: On the Discursive Limits of "Sex" (New York: Routledge, 1993).

3 Vincent J. Bertolini, "Fireside Chastity: The Erotics of Sentimental Bachelorhood in the 1850s," American Literature 68 (December 1996): 707-38.

4 Shirley Samuels, ed., The Culture of Sentiment: Race, Gender, and Sentimentality in Nineteenth-Century America (New York: Oxford Univ. Press, 1992).

5 Lora Romero, Home Fronts: Domesticity and Its Critics in the Antebellum United States (Durham, N.C.: Duke Univ. Press, 1997), 112.

6 Vermont dialect tale and sketch writer Rowland Robinson (1833-1900) and Maine poet Edwin Arlington Robinson (1869-1935).

7 Josephine Donovan, New England Local Color Literature: A Woman's Tradition (New York: Ungar, 1983), and "Breaking the Sentence: LocalColor Literature and Subjugated Knowledges," in In the (Other) American Traditions, ed. Joyce W. Warren (New Brunswick, N.J.: Rutgers Univ. Press, 1993), 226-43; Judith Fetterley and Marjorie Pryse, eds., American Women Regionalists, 1880-1910 (New York: Norton, 1992); and Susan K. Harris, Nineteenth-Century American Women's Novels: Interpretive Strategies (Cambridge, Eng.: Cambridge Univ. Press, 1990).

8 Richard Brodhead, Cultures of Letters: Scenes of Reading and Writing in Nineteenth-Century America (Chicago: Univ. of Chicago Press, 1993), $107-76$.

9 Henry Wadsworth Longfellow, ed., Poems of Places, 31 vols. (Boston: Houghton, Mifflin, 1876-1879).

10 Eugene E. Miller, "Richard Wright and Gertrude Stein," Black American Literature Forum 16 (fall 1982): 107-12; see also Michael North's conjecture about what to make of Wright's reaction in The Dialect of Modernism: Race, Language, and Twentieth-Century Literature (New York: Oxford Univ. Press, 1994), 76.

11 Nancy Bentley, The Ethnography of Manners (Cambridge, Eng.: Cambridge Univ. Press, 1995).

12 Amy Kaplan, The Social Construction of American Realism (Chicago: Univ. 
of Chicago Press, 1988), 9; Daniel Borus, Writing Realism: Howells, James, and Norris in the Mass Market (Chapel Hill: Univ. of North Carolina Press, 1989), particularly chap. 6 .

13 Mike Weaver, William Carlos Williams: The American Background (Cambridge, Eng.: Cambridge Univ. Press, 1971), 4.

14 Philip Fisher, "Democratic Social Space: Whitman, Melville, and the Promise of American Transparency," Representations 24 (fall 1988): 60101; introduction to The New American Studies: Essays from "Representations" (Berkeley and Los Angeles: Univ. of California Press, 1991); and Still the New World: Inventing the Conditions of Culture in America (forthcoming, Harvard Univ. Press).

15 Wai Chee Dimock, Residues of Justice: Literature, Law, Philosophy (Berkeley and Los Angeles: Univ. of California Press, 1996).

16 Among significant books on print culture history, Susan CoultrapMcQuin's Doing Literary Business: American Women Writers in the Nineteenth Century (Chapel Hill: Univ. of North Carolina Press, 1990) and Patricia Okker's Our Sister Editors: Sarah J. Hale and the Tradition of Nineteenth-Century American Women Editors (Athens: Univ. of Georgia Press, 1995) take gender and (in Okker's case also) race as fundamental concerns. So do such recent intellectual and cultural history-oriented interpretations of authorship and literary labor as Nicholas K. Bromell's By the Sweat of the Brow (Chicago: Univ. of Chicago Press, 1993) and Michael Newberry's Figuring Authorship in Antebellum America (Stanford: Stanford Univ. Press, 1997). On the other hand, Ronald Zboray's $A$ Fictive People: Antebellum Economic Development and the American Reading Public (New York: Oxford Univ. Press, 1993) places more emphasis on aggregate patterns in publishing, distribution, and reading than on particular cultural groups; and Meredith McGill's "The Matter of the Text: Commerce, Print Culture, and the Authority of the State in American Copyright Law" (American Literary History 9 [spring 1997]: 21-59) does not deal with gender. It should be noted that the interpretative and cultural-historical reach of Bromell's and Newberry's books goes beyond the borders of "history of the book" studies as conventionally defined, but the emphasis they place on the ideology and practice of authorship and writing is congruent with such studies.

17 See Gayatri Spivak, In Other Worlds: Essays in Cultural Politics (London: Methuen, 1987), 205-11; and Diana Fuss, Essentially Speaking: Feminism, Nature and Difference (New York: Routledge, 1989), 31-37 and passim.

18 Gustavo Pérez Firmat, Life on the Hyphen: The Cuban-American Way (Austin: Univ. of Texas Press, 1994), 44.

19 Bharati Mukherjee, "Beyond Multiculturalism: Surviving the Nineties," MultiAmerica: Essays on Cultural Wars and Cultural Peace, ed. Ishmael Reed (New York: Viking, 1997), 457.

20 Henry Louis Gates Jr., “'Authenticity' or the Lesson of Little Tree," New 
York Times Book Review, 11 November 1991, 1, 26-30; see also The Signifying Monkey: A Theory of African-American Literary Criticism (New York: Oxford Univ. Press, 1988); and The Norton Anthology of African American Literature, ed. Gates and Nellie Y. McKay (New York: Norton, 1996).

21 See Paul Gilroy, The Black Atlantic: Modernity and Double Consciousness (Cambridge: Harvard Univ. Press, 1993); Werner Sollors, Neither Black Nor White Yet Both: Thematic Explorations of Interracial Literature (New York: Oxford Univ. Press, 1997); and Ann Douglas, Terrible Honesty: Mongrel Manhattan in the 1920s (New York: Farrar Straus, 1995).

22 Toni Morrison, "Unspeakable Things Unspoken: The Afro-American Presence in American Literature," Michigan Quarterly Review 28 (winter 1989), and Playing in the Dark: Whiteness and the Literary Imagination (Cambridge: Harvard Univ. Press, 1992); Dana D. Nelson, The Word in Black and White: Reading 'Race' in American Literature, 1638-1867 (New York: Oxford Univ. Press, 1993); Eric Lott, Love and Theft: Blackface Minstrelsy and the American Working Class (New York: Oxford Univ. Press, 1995).

23 Paul de Man, "The Rhetoric of Blindness," in Blindness and Insight: Essays in the Rhetoric of Contemporary Criticism, 2d ed. (New York: Oxford Univ. Press, 1971; reprint, Minneapolis: Univ. of Minnesota Press, 1983), 141.

24 Jane Addams, Democracy and Social Ethics (New York: Macmillan, 1907), 14.

25 Lauren Berlant and Michael Warner, "What Does Queer Theory Teach Us about X?” PMLA 110 (May 1995): 345; see also Fear of a Queer Planet: Queer Politics and Social Theory, ed. Michael Warner (Minneapolis: Univ. of Minnesota Press, 1993), and Berlant, note 53 below.

26 Michael Moon, Disseminating Whitman: Revision and Corporeality in "Leaves of Grass" (Cambridge: Harvard Univ. Press, 1991).

27 Robyn Wiegman, American Anatomies: Theorizing Race and Gender (Durham, N.C.: Duke Univ. Press, 1995), 156-74.

28 Wayne Booth, from The Rhetoric of Fiction (Chicago: Univ. of Chicago Press, 1961) to The Company We Keep: An Ethics of Fiction (Berkeley and Los Angeles: Univ. of California Press, 1988).

29 J. Hillis Miller, The Ethics of Reading (New York: Columbia Univ. Press, 1987); Tobin Siebers, The Ethics of Criticism (Ithaca, N.Y.: Cornell Univ. Press, 1988); Geoffrey Harpham, Getting It Right: Language, Literature, and Ethics (Chicago: Univ. of Chicago Press, 1992); Adam Newton, Narrative Ethics (Cambridge: Harvard Univ. Press, 1995); and Christopher Norris, Truth and the Ethics of Criticism (Manchester, Eng.: Manchester Univ. Press, 1994).

30 Martha Nussbaum, Love's Knowledge: Essays on Philosophy and Literature (New York: Oxford Univ. Press, 1990); Richard Rorty's many interventions start with "Method, Social Science, and Social Hope," in his Con- 
sequences of Pragmatism (Minneapolis: Univ. of Minnesota Press, 1982), 191-210; Emmanuel Levinas, Otherwise Than Being: or, Beyond Essence (1974), trans. A. Lingis (The Hague: Nijhoff, 1981); Ethics and Infinity (1982), trans. R. A. Cohen (Pittsburgh: Duquesne Univ. Press, 1985); and Charles Taylor, The Ethics of Authenticity (Cambridge: Harvard Univ. Press, 1992).

31 Gregory Jay, American Literature and the Culture Wars (Ithaca, N.Y: Cornell Univ. Press, 1997), 111, 134.

32 See William J. Bennett, ed., The Book of Virtues: A Treasury of Great Moral Stories (New York: Simon \& Schuster, 1993).

33 Jacques Derrida, in "Adieu," a eulogy to Levinas in Critical Inquiry 23 (autumn 1996), declares that "the thought of Emmanuel Levinas has awakened us" to the conception "of responsibility first of all, but of an "unlimited' responsibility that exceeds and precedes my freedom" (3).

34 Michel Foucault, Ethics: Subjectivity and Truth, ed. Paul Rabinow, trans. Robert Hurley et al. (New York: New Press, 1994), 252-301.

35 Arthur O. Lovejoy, "On the Discrimination of Romanticisms," in Essays in the History of Ideas (Baltimore: Johns Hopkins Univ. Press, 1948), 232.

36 Possibly the speaker is thinking of "In general thought and conduct I became quite thoroughly New England," although the context for this remark is emotional restraint; or "I was brought up in the primary democracy of a New England village," although DuBois's broader point is that this made him at first naively trusting in the promise of American democracy (Dusk of Dawn, in W. E. B. DuBois: Writings, ed. Nathan Huggins [New York: Library of America, 1986], 566, 574). Most likely the speaker is conflating remarks like these with a general impression of DuBois as a reformer of strenuous moral zeal.

37 E.g., Sacvan Bercovitch, The Puritan Origins of the American Self (New Haven: Yale Univ. Press, 1975); The American Jeremiad (Madison: Univ. of Wisconsin Press, 1978); and The Rites of Assent: Transformations in the Symbolic Construction of America (New York: Routledge, 1993), especially chaps. 2, 5, and 6.

38 Richard Poirier, Poetry and Pragmatism (Cambridge: Harvard Univ. Press, 1992); and Giles Gunn, Thinking across the American Grain: Ideology, Intellect, and the New Pragmatism (Chicago: Univ. of Chicago Press, 1992).

39 Paul Jay, Contingency Blues: The Search for Foundations in American Criticism (Madison: Univ. of Wisconsin Press, 1997), 158-79; and Cornel West, The American Evasion of Philosophy: A Genealogy of Pragmatism (Madison: Univ. of Wisconsin Press, 1989).

40 Richard Slotkin, Regeneration Through Violence (Middletown, Conn.: Wesleyan Univ. Press, 1973), The Fatal Environment (New York: Atheneum, 1985), and Gunfighter Nation (New York: Atheneum, 1992); Reginald Horsman, Race and Manifest Destiny: The Origins of American Racial Anglo-Saxonism (Cambridge: Harvard Univ. Press, 1981); Anders 
Stephanson, Manifest Destiny: American Expansion and the Empire of Right (New York: Hill and Wang, 1995); and William Truettner, ed., The West as America: Reinterpreting Images of the Frontier, 1820-1920 (Washington, D. C.: Smithsonian Institution Press, 1991).

41 Amy Kaplan and Donald E. Pease, eds., Cultures of United States Imperialism (Durham, N.C.: Duke Univ. Press, 1993); Eric Cheyfitz, The Poetics of Imperialism: Translation and Colonization from "The Tempest" to Tarzan (New York: Oxford Univ. Press, 1991).

42 Benedict Anderson, Imagined Communities: Reflections on the Origin and Spread of Nationalism (London: Verso, 1983).

43 See, for example, Elegant Jeremiahs: The Sage from Carlyle to Mailer (Ithaca, N.Y.: Cornell Univ. Press, 1986) by George Landow, a scholar trained in Victorian studies. In nineteenth-century U.S. studies, perhaps the most wide-ranging contribution so far is Robert Weisbuch, Atlantic Double-Cross: American Literature and British Influence in the Age of Emerson (Chicago: Univ. of Chicago Press, 1986).

44 Symbiosis, published by the University College of St. Mark and St. John, Plymouth, England.

45 Walter Benn Michaels, Our America: Nativism, Modernism, and Pluralism (Durham, N.C.: Duke Univ. Press, 1995).

46 Doris Sommer, Foundational Fictions: The National Romances of Latin America (Berkeley and Los Angeles: Univ. of California Press, 1991); José Saldivar, The Dialectics of Our America: Genealogy, Cultural Critique, and Literary History (Durham, N.C.: Duke Univ. Press, 1991), and Border Matters (Berkeley and Los Angeles: Univ. of California Press, 1997); Gloria Anzaldúa, Borderlands: The New Mestiza=La Frontera (San Francisco: Spinsters/Aunt Lute Books, 1987); Edmundo O'Gorman, The Invention of America: An Inquiry into the Historical Nature of the New World and the Meaning of Its History (Bloomington: Indiana Univ. Press, 1961); José Rabasa, Inventing America: Spanish Historiography and the Formation of Eurocentrism (Norman: Univ. of Oklahoma Press, 1993).

47 Gerald Vizenor, e.g., Crossbloods: Bone Courts, Bingo, and Other Reports (Minneapolis: Univ. of Minnesota Press, 1990); Arnold Krupat, The Voice in the Margin: Native American Literature and the Canon (Berkeley and Los Angeles: Univ. of California Press, 1989); and Louis Owens, Other Destinies: Understanding the American Indian Novel (Norman: Univ. of Oklahoma Press, 1992).

48 Sau-ling Wong, Reading Asian American Literature: From Necessity to Extravagance (Princeton, N.J.: Princeton Univ. Press, 1993), 206.

49 Maxine Hong Kingston's protagonist is a frustrated artist-figure named Whitman Ah Sing, a conflation of the opening line of "Song of Myself" and perhaps the most notorious early stereotypical Chinese figure in Euroamerican literature, Bret Harte's Ah Sin; see Tripmaster Monkey: His Fake Book (New York: Knopf, 1989).

50 Monkey, a shape-changing character perhaps entering Chinese culture 
from Hindu mythology (cf. the epic Ramayana), is the most pivotal figure in the plot of the classic Chinese novel The Journey to the West, which incidentally is based on a pilgrimage of a Buddhist monk named Tripitaka to India (see C. T. Hsia, The Classic Chinese Novel: A Critical Introduction [New York: Columbia Univ. Press, 1968], 115-64). Like Tripmaster Monkey, Journey to the West is a comic fabulation in which the quest narrative is both enacted and deconstructed.

51 Ralph Waldo Emerson, "Experience," in Complete Works, vol. 3, ed. Joseph Slater et al. (Cambridge: Harvard Univ. Press, 1983), 47.

52 Lisa Lowe, Immigrant Acts (Durham, N.C.: Duke Univ. Press, 1996); cf. the journal Diaspora, to which Lowe contributed the lead article in the first issue (spring 1991).

53 Lauren Berlant, The Queen of America Goes to Washington City: Essays on Sex and Citizenship (Durham, N.C.: Duke Univ. Press, 1997).

54 Patricia Limerick, The Legacy of Conquest: The Unbroken Past of the American West (New York: Norton, 1987); Ramón A. Gutiérrez, When Jesus Came, the Corn Mothers Went Away (Stanford: Stanford Univ. Press, 1991).

55 Jean Baudrillard, America (1986), trans. Chris Turner (London: Verso, 1988).

56 See Cheryll Glotfelty and Harold Fromm, eds., The Ecocriticism Reader: Landmarks in Literary Ecology (Athens: Univ. of Georgia Press, 1996), xviii and passim.

57 John Elder, Reading the Mountains of Home (Cambridge: Harvard Univ. Press, 1998); Kent Ryden, Mapping the Invisible Landscape: Folklore, Writing, and the Sense of Place (Iowa City: Univ. of Iowa Press, 1993); Louise Westling, The Green Breast of the New World: Landscape, Gender, and American Fiction (Athens: Univ. of Georgia Press, 1996); Vera Norwood, Made from This Earth: American Women and Nature (Chapel Hill: Univ. of North Carolina Press, 1993); Annette Kolodny, The Lay of the Land: Metaphor as Experience and History in American Life and Letters (Chapel Hill: Univ. of North Carolina Press, 1975); Kolodny, The Land Before Her: Fantasy and Experience of the American Frontiers, 1630-1860 (Chapel Hill: Univ. of North Carolina Press, 1984); and Carl G. Herndl and Stuart Brown, eds., Green Culture: Environmental Rhetoric in Contemporary America (Madison: Univ. of Wisconsin Press, 1996). Caveat lector: not all these scholars would feel comfortable being categorized as "ecocritics" and/or "ecofeminists," as B does here. 